\title{
Tree Diversity, Stand Structure, and Community Composition in an Island Forest of Pulau Perhentian Besar, Terengganu
}

\author{
F Pardi ${ }^{1 *}$, M N Mohd Said ${ }^{2}$, A Ismail ${ }^{1}$, N J Sidik ${ }^{1}$, K A Radzun ${ }^{1}$, H N Ruziman ${ }^{1}$, S S Kasri ${ }^{3}$ \\ ${ }^{I}$ School of Biology, Faculty of Applied Sciences, Universiti Teknologi MARA, Shah Alam, 40450 Selangor, Malaysia \\ ${ }^{2}$ School of Environmental and Natural Resource Sciences, Faculty of Science and Technology, Universiti Kebangsaan Malaysia, 43600, \\ UKM Bangi, Selangor \\ ${ }^{3}$ Pusat Asasi, Universiti Teknologi MARA, 43800 Dengkil, Selangor, Malaysia \\ **Corresponding author E-mail: faezahpardi@salam.uitm.edu.my
}

\begin{abstract}
The Perhentian Island Archipelago comprising of 11 small islands is located in the state of Terengganu are among the biodiversity rich localities in Peninsular Malaysia. Perhentian Besar with approximately 867 hectares is one of the inhabited island and become the centre of tourism besides Perhentian Kecil. Island is well known as a place for many endemic and endangered living organism as previously demonstrated on other similar forested islands in Southeast Asia. However, there is little attention and effort of protection has been received by the terrestrial ecosystems that reside nearby the coastal. Thus, the present study investigates on tree diversity, stand structure and community composition in the island of Perhentian Besar, Terengganu. Forest plot of 0.5 hectare was established to analyze the floristic composition of tree taxa. The plot was divided into 10 subplots of $25 \mathrm{~m} \mathrm{x} 20 \mathrm{~m}$. All trees with $5 \mathrm{~cm}$ diameter breast height (dbh) and above were tagged, measured for dbh size, recorded and identified. Voucher specimens were taken for further verification purposes. A total of 102 tree species were recorded comprising of 28 families and 65 genera. Rubiaceae had the highest number of species (11 species) and with regards to relative dominance, Shorea leprosula (Dipterocarpaceae) gave the highest importance value index (IVi) for species with a value of $8.45 \%$. The Shannon-Weiner Diversity Index (H') was considered high in the present study with $3.94\left(H^{\prime} \max =4.62\right)$ and the Evenness Index (E) value of 0.85 indicated that all species in the present study are almost equally abundant. The forest stand structure had a reverse J-shaped curve for tree size-class distributions as frequently observed in many natural forests, which indicated that the forest stand in the study site had a good recruitment patterns and also a main feature of matured forest in Peninsular Malaysia. The present study will help us to understand the pattern of tree species composition, diversity and forest ecosystem dynamic in Pulau Perhentian Besar.
\end{abstract}

Keywords: ecology; Pulau Perhentian Besar ; species composition ; species diversity ; tree species,

\section{Introduction}

Ecosystem study are usually difficult to understand and conceptualized as it is not easy to delimitate physically [1]. Hence, island ecosystem have often been considered and used as a model to comprehend processes of evolution due to its geographical isolation factor from the biological populations on the mainland [2] [3]. Every single part of the island ecosystems including its populations and communities are vulnerable yet resistance to the ecosystem challenges despite of its geographical limitation with vital properties, processes and interactions occur in a manageable way [4]. However, understanding on one of the basic biotic elements of the island ecosystem such as trees is important in order to know more on such complex interactions. Among special features of tree islands are

sensitive to presence of exotic species and any changes in hydrologic condition. Thus, tree island can be used as an indicator of the potential impacts of changes to hydrologic conditions and provide vital relationship between land and ocean [5]. Isolated islands constitute important centers of endemism [6] as they can provide secure sanctuary and shelter for species, which originated from mainland areas [7]. Unfortunately, many forested tropical islands have most often been heavily impacted by anthropogenic activities and their biodiversity has been jeopardized [8]. Nonetheless, some islands at the northeast coast of Peninsular Malaysia, mainly Pulau Perhentian, has many astounding features; with high biodiversity area, humid climate and famous for its ecotourism activities. Therefore, the island forest has many ecological, socio-economics importance and impact to the local and global community [9].

Pulau Perhentian comprises of two islands called Perhentian Kecil and Perhentian Besar. The islands are located about $21 \mathrm{~km}$ off the Kuala Besut jetty. It is among one of the islands in Terengganu that is being frequented by tourist as vacation spot for leisure, sight-seeing, diving, snorkeling and jungle trekking. Pulau Perhentian Kecil is inhabited by more than 2,000 local people in a small township and a small village called Kampung Pasir Hantu. Both Pulau Perhentian Kecil and Besar are separated by a very narrow channel with strong water current [10]. Pulau Perhentian Besar was enacted as the Marine Protected Area system and had been gazetted as Fisheries Protected Areas under Fisheries Act of 1985.

Unlike many terrestrial ecosystem, there were little attention and effort on protecting the diversity of flora in the coastal forest including islands in the off-coast islands of Terengganu. Therefore, 
in this paper we provide the tree species diversity, stand structure and community composition occurring on one of the island of the Pulau Perhentian group, i.e. Pulau Perhentian Besar. The findings including distribution and abundance of tree species are useful in our understanding on the dynamic of forest ecosystem and conservation management purposes.

\section{Materials and method}

\subsection{Study Area}

Pulau Perhentian Besar, 0553'286" N, 102 ${ }^{\circ} 44^{\prime} 783^{\prime \prime}$ E, with granitic feature forested island habitat lying off the northeast coast of Peninsular Malaysia. The granite bedrock only allows the development of thin and rocky soil; however, deeper soils are known to have develop in more sheltered valley area [11]. Most of the island of Perhentian Besar consist of virgin forests comprising of mainly Dipterocarp forest, with both Dipterocarpus and Shorea species being found [12]. Our study site consists of old secondary forest that stretches from the sandy rocky adjacent to the coastal area until the hilly rocky area of the island. Photograph of the study site is shown in Figure 1.

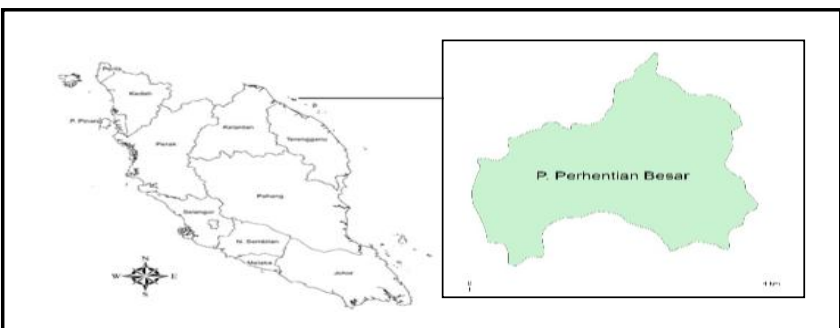

Fig 1: Map of Peninsular Malaysia showing the location Pulau Perhentian Besar, Terengganu

\subsection{Tree species enumeration}

Ten study plots of $25 \times 20 \mathrm{~m}$ each (total area of 0.5 hectare) were established at the study area. In each plot, all trees with diameter at breast height (dbh) of $5 \mathrm{~cm}$ and above were tagged and measured its diameter. Collections of specimens were carried out with the help of aborigines (Orang Asli) to climb the trees; or the use of catapult to drop off the leaf samples; and the use of aluminium pruner. Leaves specimens of each measured tree were collected for preparation of voucher specimens and identification. Every specimen collected in the plots were tagged carefully and pressed between newspapers then preserved in alcohol. The specimens were kept in plastic bags and the plastic bags were tied to form an air-tight condition. In the laboratory, the specimens were transferred to dry newspapers. The pressed specimens were then ovendried at $55^{\circ} \mathrm{C}$ for seven to ten days depending on the type, thickness of the leaf and also the presence of fruits or flowers. The method for pressing the specimens was based on Bridson and Forman [28]. Species identification was made possible up to species level by referring to the keys described in Tree Flora of Malaya [9][10][11][12].

\subsection{Data Analysis}

Data of all tree species were tabulated in Microsoft Excel according to its habitat and were summarized to describe species composition and abundance of the tree communities at each site. Several diversity and richness indices were calculated, amongst them were Shannon Diversity Index and Margalef's Richness Index [17]. Comparison of species richness between forests was made using Paleontological Statistics (PAST) Version 2.17 [18] and EcoSim (Null Modelling Software for Ecologist) [19].

\section{Results and discussion}

\subsection{Floristic composition}

Based on the inventory, we recorded a total of 702 trees with diameter at breast height $(\mathrm{dbh})$ of $5 \mathrm{~cm}$, consisted of 102 species from 65 genera and 28 families. The finding of this study was then compared to the previous studies [20] [21] [22] that focused on the similar forested islands in Peninsular Malaysia as shown in Table 1. Several studies on swamp forest, alluvium soil forest, limestone hill forest and dipterocarp forest at Gunung Mulu National Park, Sarawak, reported that differences in species composition between the forest habitats could be due to differences in soil chemical properties of the different study areas [23]. Overall, the most speciose family within the 0.5 -ha plot was the Rubiaceae (11 species) followed by Ebenaceae ( 9 species) and Guttiferae ( 8 species) while 8 families were singletons (represented by only one species) which were Apocynaceae, Celastraceae, Elaeocarpaceae, Fagaceae, Ixonanthaceae, Lecythidaceae, Oxalidaceae and Simaroubaceae. Similar observation have also reported Rubiaceae as the most speciose family of a coastal hill forest in Perak [24] as well as in the oldest forest reserve in Bukit Nanas Forest Reserve, Malaysia [25]. This is not surprising because Rubiaceae is reported as one of the five most species-rich flowering plant families comprising of 13,000 species; 620 genera, more than 40 tribes, and three subfamilies that is widely distributed at all continents including on the Antarctic Continent but most taxa occured in tropical or subtropical areas.

Table 1: Number of tree species with comparison of the other studies focusing on the island

\begin{tabular}{llc}
\hline \multicolumn{1}{c}{ Study } & \multicolumn{1}{c}{ Location } & \multicolumn{1}{c}{$\begin{array}{c}\text { Number of tree } \\
\text { species recorded }\end{array}$} \\
\hline Present study & $\begin{array}{l}\text { Pulau Perhentian Besar } \\
(0.5 \text { ha) }\end{array}$ & 102 \\
Senterre et al. & $\begin{array}{l}\text { Pulau Babi Tengah, } \\
\text { Johor }\end{array}$ & 77 \\
Rohaiza (2011) & $\begin{array}{l}\text { Pulau Singa Besar, } \\
\text { Langkawi (0.5 ha) } \\
\text { Pulau Timun Langkawi } \\
\text { (0.5 ha) } \\
\text { Gunung Matchinchang } \\
\text { Forest Reserve, Lang- } \\
\text { kawi (2.6 ha) }\end{array}$ & 75 \\
\hline
\end{tabular}

The diameters of all trees sampled ranged from $5.0 \mathrm{~cm}$ to $85.2 \mathrm{~cm}$ of which $64.4 \%$ of the trees ( 452 trees) have a DBH size ranging from $5.0 \mathrm{~cm}$ to $14.9 \mathrm{~cm}$. Diameter class distribution of the forest in each study site was strongly size-dependent and showed a reversed J-shaped curve (Figure 2). The inverse J-shape curve of the DBH distribution in the present study is in accordance with other tropical forests including on forested island [20][21][27] and it indicates that the forest stands in the study sites has good recruitment patterns which rich sampling bank [27], and it is also a main feature of matured forest in Peninsular Malaysia [28].

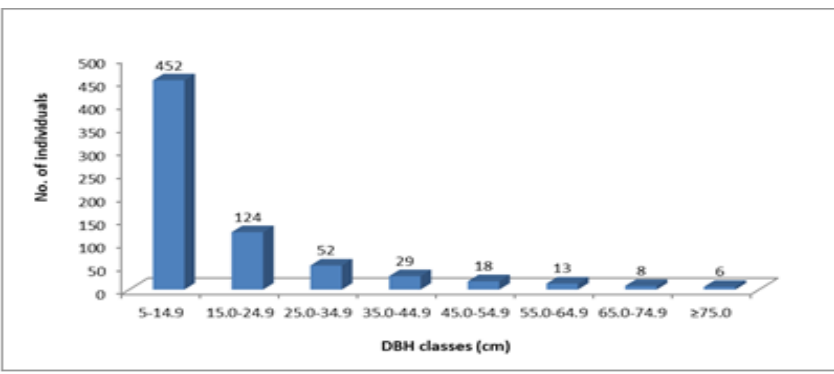

Fig 2: Stand structure of trees at different DBH classes in all study plots at the Pulau Perhentian Besar, Terengganu 


\subsection{Abundance and species importance}

Density of trees in all plots was 1404 trees/ha of which Dipterocarpaceae contributed the highest density with 328 trees/ha (23.4\%) followed by Rubiaceae with 106 trees/ha (7.5\%) (Table 2). Hopea dryobalanoides (Dipterocarpaceae) with 120 trees/ha was the species that had the highest density, whilst Symplocos adenophylla (Symplocaceae) was ranked the second with 86 trees/ha in the study plot (Table 2). Furthermore, the study plot showed a total tree basal area (BA) of $53.71 \mathrm{~m}^{2} /$ ha of which Dipterocarpaceae dominated the highest BA with values of $23.35 \mathrm{~m}^{2}$ /ha followed by Myrtaceae with $4.68 \mathrm{~m}^{2}$ /ha (Table 2). At species level, Shorea leprosula (Dipterocarpaceae) was the species with the highest total BA in the plot with value of $10.04 \mathrm{~m}^{2} / \mathrm{ha}$, whilst Dipterocarpus crinitus (Dipterocarpaceae) represented the second highest BA of $8.08 \mathrm{~m}^{2}$ /ha (Table 2). A similar observation was also reported at deciduous broad leaves forest and semi-deciduous forest in Sakaerat Reserve, north eastern Thailand where Dipterocarpaceae contributed the largest BA of $9.53 \mathrm{~m}^{2} / \mathrm{ha}$ and 15.14 $\mathrm{m}^{2} /$ ha, respectively [29].

Based on the calculated Importance Value Index (IVi), Shorea leprosula (Dipterocarpaceae) dominated the highest importance value index (IVi) of $8.45 \%$, followed by Dipterocarpus crinitus (Dipterocarpacae) with an index value of $7.74 \%$ (Table 2). Dipterocarpacea recorded the highest family importance value index (FIVi) with $24.54 \%$ while Euphorbiaceae was on the second rank with FIVi of $6.57 \%$ (Table 2). The results show that none of the species and family in the study plot is considered as absolute dominant because only the species and family with IV $i$ of more than $10 \%$ and $40 \%$, respectively is considered to have absolute dominance in a particular area [30].

Table 2: Summary of tree density, basal area (BA) and Importance Value $\left(\mathrm{IV}_{\mathrm{i}}\right)$ of two leading families and species at 10 plots of Pulau Perhentian Besar, Terengganu.

\begin{tabular}{|c|c|c|c|}
\hline & Family & & Species \\
\hline \multirow{2}{*}{$\begin{array}{l}\text { Density } \\
\text { (trees/ha) }\end{array}$} & Dipterocarpaceae & 328 & Hopea dryobalanoides 120 \\
\hline & Rubiaceae & 106 & Symplocos adenophylla 86 \\
\hline \multirow{2}{*}{$\begin{array}{l}\text { Basal } \\
\text { Area } \\
\left(\mathrm{m}^{2} \mathrm{ha}^{-1}\right)\end{array}$} & Dipterocarpaceae & 23.35 & $\begin{array}{ll}\text { Shorea leprosula } \quad 10.04 \\
\end{array}$ \\
\hline & Myrtaceae & 4.68 & Dipterocarpus crinitus 8.08 \\
\hline \multirow[t]{2}{*}{$\mathrm{IV}_{\mathrm{i}}(\%)$} & Dipterocarpaceae & 24.54 & Shorea leprosula $\quad 8.45$ \\
\hline & Euphorbiaceae & 6.57 & Dipterocarpus crinitus 7.74 \\
\hline
\end{tabular}

\subsection{Species-area curve}

Species accumulation curve/species-area curve plots the cumulative number of species recorded as a function of sampling effort and illustrate the increase in the total number of species encountered during the process of data collection [31]. Larger areas tend to contain larger numbers of species, and empirically, the relative numbers seem to follow systematic mathematical relationships. In all the 10 plots of the study area, the first plot with an area of 0.05 ha recorded 29 species and subsequent increase of the plot area to $0.1 \mathrm{ha}$, result an increase in total number of species to 49 , with addition of 20 other species (Table 3). A gradual accumulation was observed from 0.15 ha to 0.35 ha, where the species number increased from 64 species to 98 species. Further increase in plot area to the total area of 0.50 ha indicates a small increase in species number (less than 3 species), and a species area curve (Figure 3) illustrates this pattern.

Table 3: Total numbers of species and the increase in tree species $(\geq 5 \mathrm{~cm}$ DBH) a crossed 0.05-ha intervals in the 10 plots at Pulau Perhentian Besar, Terengganu

\begin{tabular}{cccc}
\hline & & \multicolumn{2}{c}{ No. of species PPB } \\
\cline { 3 - 4 } Plot & Size (ha) & Total sp. & Total species increase \\
\hline 1 & 0.05 & 29 & 0
\end{tabular}

\begin{tabular}{cccc}
2 & 0.1 & 49 & 20 \\
3 & 0.15 & 64 & 15 \\
4 & 0.2 & 75 & 11 \\
5 & 0.25 & 85 & 10 \\
6 & 0.3 & 92 & 7 \\
7 & 0.35 & 98 & 6 \\
8 & 0.4 & 100 & 2 \\
9 & 0.45 & 101 & 1 \\
10 & 0.5 & 102 & 1 \\
\hline
\end{tabular}

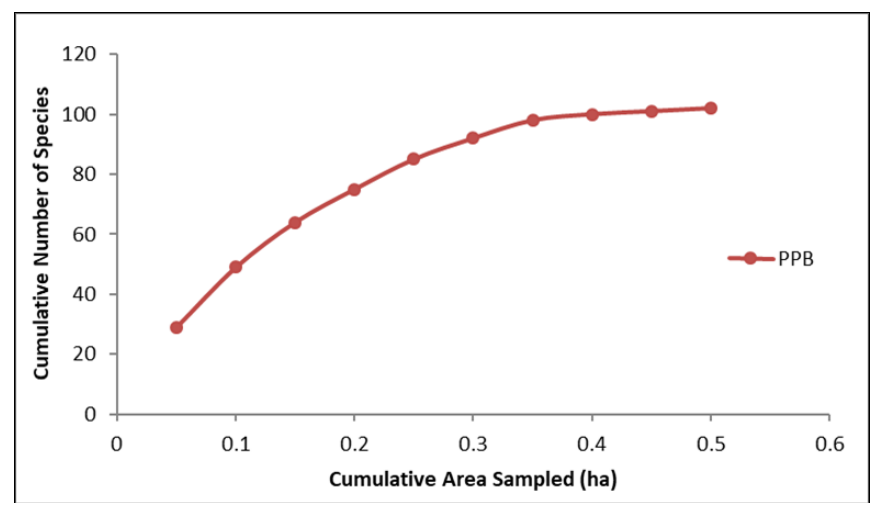

Fig 3: Species-area curve of tree communities $(\geq 5 \mathrm{~cm} \mathrm{DBH})$ in the 10 study plots at Pulau Perhentian Besar, Terengganu.

The mean cumulative numbers of species per 0.05 ha in the study sites was 10.2 species, while the total additional number of species of 0.50 ha in the present study was 102 species. Figure 3 also showed that the study area of 0.50 ha in the Pulau Perhentian Besar were almost the optimum size to capture the species richness of the area, whereby a plateau is nearly reached at the top of the graph; nevertheless, no clear asymptote is obtained, as the number of species was still on increase when the survey area is increased. Other studies in lowland forests such as of Ayer Hitam Forest Reserve [32] and Pasoh Forest Reserve [28] also showed that species number continues to increase even over 5-30 hectares of survey area. This pattern is in accordance with a study of three 50-ha plots at various study sites; Pasoh Forest Reserve, Barro Colorado Island, Panama and Mudumalai Game Reserve in the state of Tamil Nadu, of which they observed species accumulation curves of a tropical rain forest showed no asymptote that approaching the curves in any scale compared to the temperate forest [33]. This is because tropical forests support high species richness, whereby the increase of the study area would cause an increase in number of species even just one species would be added. According to [33], the asymptote was not reached in the accumulation curve at any scale as demonstrated in the three 50-ha inventory plots including the Pasoh Forest Reserve, Peninsular Malaysia, where tree species richness continued to accumulate up to and beyond 50 ha. In addition, [33] also argued that the general concept of asymptote in the accumulation curve at 1-3 ha probably comes from temperate forest ecosystem sharply defined by edaphic and climatic regimes that can be fully enumerated.

\subsection{Conservation status}

Species that are Critically Endangered (CR), Endangered (EN) and Vulnerable (VU) are collectively referred as threatened. All species in the study plots were compared with the IUCN list, and 17 species out of 102 tree species in the Pulau Perhentian Besar were listed in Red List of Threatened Species (Table 4). Six species of Dipterocarpaceae and one species of Sapotaceae were categorized as threatened. Dipterocarpaceae has the largest number of threatened species of six, or $85.7 \%$ of all threatened species at all study plots. Pulau Perhentian Besar also recorded ten lower risk/least concern species from Burseraceae (three species); Guttiferae (three species); while Celastraceae, Myristicaceae, Ochnaceae and Sapotaceae each with one species, respectively. 
The largest percentage of threatened species in dipterocarps is because the family has high commercial value and also primary source of timber industries in Malaysia. Many studies in various forest types in Peninsular Malaysia documented dipterocarp species as the most threatened family [34] [35] [36]. This is also similar with [37] listed 92 taxa of Peninsular Malaysia dipterocarps under the threatened category of the IUCN Red List. The highest number of threatened species in one family give us signal that the family need more attention in conservation. The uncontrolled land transformation activities and illegal logging activities can decrease dipterocarps population in the wild.

Conserving native plant diversity and threatened species may require actively protecting and restoring species-rich habitats and areas with it high uniqueness. The Pulau Perhentian Besar has highly unique sites to harbour many endemic and threatened species that need of conservation and it is essential to protect the forested island with minimise threats by any means possible.

Table 4: The IUCN Conservation status of tree species in Pulau Perhentian Besar

\begin{tabular}{|c|c|c|}
\hline FAMILY & SPECIES & $\begin{array}{l}\text { IUCN } \\
\text { STATUS }\end{array}$ \\
\hline BURSERACEAE & $\begin{array}{l}\text { Canarium littorale Blume } \\
\text { Dacryodes costata (Benn.) H.J. }\end{array}$ & $\mathrm{LR} / \mathrm{lc}$ \\
\hline BURSERACEAE & $\begin{array}{l}\text { Lam } \\
\text { Santiria apiculata Benn. var. }\end{array}$ & $\mathrm{LR} / \mathrm{lc}$ \\
\hline BURSERACEAE & apiculata & $\mathrm{LR} / \mathrm{lc}$ \\
\hline $\begin{array}{l}\text { CELASTRACEAE } \\
\text { DIPTEROCARPACEA }\end{array}$ & Lophopetalum wightianum Arn. & LR/lc \\
\hline $\begin{array}{l}\text { E } \\
\text { DIPTEROCARPACEA }\end{array}$ & Dipterocarpus crinitus Dyer & En \\
\hline $\begin{array}{l}\text { E } \\
\text { DIPTEROCARPACEA }\end{array}$ & Shorea foxworthyi Symington & CR \\
\hline $\begin{array}{l}\text { E } \\
\text { DIPTEROCARPACEA }\end{array}$ & Shorea glauca King & En \\
\hline $\begin{array}{l}\text { E } \\
\text { DIPTEROCARPACEA }\end{array}$ & Shorea lepidota (Korth.) Blume & CR \\
\hline $\begin{array}{l}\text { E } \\
\text { DIPTEROCARPACEA }\end{array}$ & Shorea leprosula Miq & En \\
\hline $\mathrm{E}$ & Vatica mangachapoi Blanco & En \\
\hline GUTTIFERAE & $\begin{array}{l}\text { Calophyllum tetrapterum Miq. } \\
\text { Cratoxylum arborescens (Vahl) }\end{array}$ & $\mathrm{LR} / \mathrm{lc}$ \\
\hline GUTTIFERAE & Blume var. arborescens & $\mathrm{LR} / \mathrm{lc}$ \\
\hline GUTTIFERAE & $\begin{array}{l}\text { Garcinia maingayi Hook.f. } \\
\text { Knema furfuracea (Hook.f. \& }\end{array}$ & $\mathrm{LR} / \mathrm{lc}$ \\
\hline MYRISTICACEAE & $\begin{array}{l}\text { Thomson) Warb } \\
\text { Brackenridgea hookeri (Planch.) }\end{array}$ & $\mathrm{LR} / \mathrm{lc}$ \\
\hline OCHNACEAE & $\begin{array}{l}\text { A. Gray } \\
\text { Madhuca penicillata (King \& }\end{array}$ & $\mathrm{LR} / \mathrm{lc}$ \\
\hline SAPOTACEAE & $\begin{array}{l}\text { Gamble) H.J. Lam } \\
\text { Palaquium maingayi (C.B. }\end{array}$ & $\mathrm{Vu}$ \\
\hline SAPOTACEAE & Clarke) King \& Gamble & $\mathrm{LR} / \mathrm{lc}$ \\
\hline
\end{tabular}

Note: $\mathrm{LR}=$ Lower risk, $1 \mathrm{c}=$ least concern, $\mathrm{CR}=$ Critically Endangered, $\mathrm{EN}=$ Endangered and $\mathrm{VU}=$ Vulnerable.

\section{Conclusion}

The floristic study showed that the Pulau Perhentian Besar is composed of diverse and unique flora communities, whereby high species richness was displayed. The stand structure of tree communities in the study sites were dominated by small trees $<15 \mathrm{~cm}$ dbh with a reverse J-shaped pattern, and it reflects a high regeneration potential of the forest and also a typical for a mature stand, with many small stems compared to few large ones. No absolute species dominance was recorded in the study area; which is a common character of the tropical forest community where there is a lack of species dominance and high species diversity. It is important that the study and monitoring of the biodiversity at Pulau Perhentian Besar be continued to ensure that actions can be taken immediately if any detrimental development occurs before the biodiversity is fully explored and documented. Furthermore, this island have the potential to support conservation and tourism activities.

\section{Acknowledgement}

The authors would like to thank the Terengganu State Forestry Department and local authorities for giving us the permission to conduct our research in Pulau Perhentian, Terengganu. Besides, we would like to thank the School of Environmental and Natural Resource Sciences, Faculty of Science and Technology, Universiti Kebangsaan Malaysia for all the facilities including laboratory apparatus and materials. We are also grateful to Ahmad Fitri Zohari for species identification. The acknowledgment continue with financial support from the Universiti Kebangsaan Malaysia through Research University Grant GUP-2013-056 and the Research Management Institute (RMI), Universiti Teknologi MARA (UiTM) under the Excellence Fund (600-IRMI/Dana KCM 5/3/LESTARI (122/2017).

\section{References}

[1] Oldeman RAA, Forests: Elements of Silvology, New York:Springer-Verlag, (1990), p. 624

[2] Leigh EG, Hladik A, Hladik CM \& Jolly A (2007), The biogeography of large islands, or how does the size of the ecological theater affect the evolutionary play?, Revue d'Ecologie-La Terre et la Vie 62: $105-168$

[3] Whittaker RJ, Triantis KA \& Ladle RJ (2008), A general dynamic theory of oceanic island biogeography. Journal of Biogeography 35(6): 977-994.

[4] Vitousek PM, Loope LL, Adsersen H \& D’Antonio CM (1996), Island ecosystems: do they represent "natural experiments" in biological diversity and ecosystem function?. In: Functional Roles of Biodiversity. A Global Perspective(eds Mooney HA, Cushman JH, Medina E, Sala OE \& Schulze E-D).John Wiley \& Sons Ltd, Chichester, UK, pp. 245-25

[5] Srivastava DS \& Vellend M (2005), Biodiversity-ecosystem Function Research: it is Relevant to Conservation, Annual Review of Ecology, Evolution and Systematic 36, 267-338.

[6] Kier G, Kreft H, Lee TM, Jetz W, Ibisch PL, Nowicki C, Mutke J $\&$ Barthlott W. A global assessment of endemism and species richness across island and mainland regions. Proceedings of the $\mathrm{Na}$ tional Academy of Sciences of the United States of America, Vol 106, No. 23, 2009, pp: 9322-9327.

[7] Cronk QCB (1997), Islands: stability, diversity, conservation. Biodiversity and Conservation, 6(3): 477-493.

[8] Denslow JS (2003), Weeds in paradise: Thoughts on the invasibility of tropical islands. Annals of the Missouri Botanical Garden, 90(1): 119-127.

[9] Khairil M, Nashriyah M, Norhayati N, Shahril A, \& Nur Fatihah (2012), Tree Species Composition, Diversity and above Ground Biomass of Two Forest Types at Redang Island, Peninsula Malaysia. Walailak Journal of Science and Technology 10(1): 77-90.

[10] Perhentian Island. Perhentian Island, Pulau Perhentian, Perhentian Kecil \& Besar, Kuala Besut, Terengganu, Malaysia. http://www. terengganutourism.com/pulau_perhentian. htm. 2018, Downloaded 19th July 2018.

[11] David G, Roslan A, Mamat MA, Abdullah MT \& Abdulmula AH (2016), A Brief Survey On Birds From Pulau Perhentian Besar, Terengganu, Journal of Sustainability Science and Management, Special Issue Number I: 11-18

[12] Tamblyn A, Turner C, O’Malley R, Hughes T, Hardingham S \& Roberts H (2005), Malaysian Tropical Forest Conservation Project. Report of the Perhentian Phase, London, United Kingdom, p.111.

[13] Ng FSP (ed.) (1978), Tree Flora of Malaya. A manual for foresters, Vol. 3. Longman Malaysia Sdn. Bhd. Kuala Lumpur, p.339.

[14] Ng FSP (ed.) (1989), Tree Flora of Malaya. A manual for foresters, Vol. 4. Longman Malaysia Sdn. Bhd. Kuala Lumpur, p. 549.

[15] Whitmore TC (ed.) (1972), Tree Flora of Malaya. Vol. 1, Malayan Forest Records No. 26. Longman Malaysia Sdn. Bhd., Kuala Lumpur, p. 471 
[16] Whitmore TC (ed.) (1973), Tree Flora of Malaya. Vol. 2, Malayan Forest Records No. 26. Longman Malaysia Sdn. Bhd., Kuala Lumpur, p. 444.

[17] Magurran AE \& McGill BJ (2011), Biological diversity: frontiers in measurement and assessment. Oxford University Press, Oxford, p. 368.

[18] Hammer $\varnothing$, Harper DAT \& Ryan PD. PAST: Paleontological statistics software package for education and data analysis, Palaeontologia Electronica, available online https://folk.uio.no/ohammer/past/index_old.html

[19] Gotelli NJ \& Entsminger GL (2013), EcoSim: Null models software for ecology, Ver. 1.0, available online http://www.uvm.edu/ ngotelli/EcoSim/EcoSim.html

[20] Raffae A (2003), Tree Species Diversity, Biomass and Economic Value of 2.6 ha Plot in Langkawi Island. Master Degree Thesis, National University of Malaysia.

[21] Rohaiza D (2011). The Diversity and Community Structure of Tree Species at Pulau Timun and Pulau Singa Besar Reserve Forest, Langkawi Island. Master Degree Thesis. National University of Malaysia.

[22] Senterre B, Chew MY \& Chung RCK (2015), Flora and Vegetation of Pulau Babi Tengah, Johor, Peninsular Malaysia. Check List, 11(4): 1714.

[23] Proctor J, Anderson JM, Chai P \& Vallack HW (1983), Ecological studies in four contrasting lowland rain forests in Gunung Mulu National Park, Sarawak. IV. Associations between tree distributions and soil factors. Journal of Ecology, 72: 475-493.

[24] Ghollasimood S, Faridah-Hanum I, Nazre M \& Karnziah AK (2011), Tree species composition and structure of a coastal hill forest in Pulau Pangkor, Malaysia. Journal of Agricultural Science 3(4), 172-187.

[25] Salleh N, Azeman S, Kiew R, Kamin I \& Cheng Kong R (2017) Plant Checklist of the Bukit Nanas Forest Reserve, Kuala Lumpur, Malaysia, One Ecosystem 2, p.41.

[26] Bremmer B \& Eriksson O (2009), Time Tree of Rubiaceae: Phylogeny and Dating the Family, Subfamilies and Tribes. International Journal of Plant Sciences 170, 766-793.

[27] Zhang ZH, Hu G, Zhu JD \& Ni J (2012), Stand structure, woody species richness and composition of subtropical karst forests in Maolan, South-West China. Journal of Tropical Forest Science, 24(4): 498-506.

[28] Manokaran N, La Frankie JV, Kochummen KM, Quah ES, Klahn J, Ashton PS \& Hubbell SP (1990), Methodology for the fifty hectare research plot at Pasoh Forest Reserve. Research Pamphlet No. 104, Forest Research Institute of Malaysia (FRIM), Kuala Lumpur p. 69.

[29] Lamotte S, Gajaseni J \& Malaisse F (1998), Structure diversity in three forest types of north-eastern Thailand (Sakaerat Reserve, Pak Tong Chai). Biotechnology, Agronomy, Society and Environment 2 (3):192-202.

[30] Curtis JT \& Macintosh RP (1951), An upland continuum in the prairie-forest border region of Wisconsin. Ecology, 32: 476-496.

[31] Newton AC (2007), Forest ecology and conservation: A handbook of techniques. Oxford University Press, Oxford, UK, p.454.

[32] Lepun P (2002), Tree species composition and distribution in Ayer Hitam Forest Reserve, Puchong, Selangor. MSc. Thesis, Universiti Putra Malaysia, Serdang. (unpublished).

[33] Condit R, Hubbell SP, LaFrankie JV, Sukumar R, Manokaran N, Foster RB \& Ashton PS (1996), Species-area and speciesindividual relationship for tropical trees. A comparison of three 50 ha plots. Journal of Ecology 84: 549-562.

[34] Mazlin K (2013), Struktur komuniti pokok, taburan dan hubungan dengan faktor tanah dalam hutan pusingan kedua di Jengka, Pahang. MSc. Thesis. Universiti Kebangsaan Malaysia, Bangi. (unpublished).

[35] Ahmad Fitri Z (2013), Community structure, species diversity and relationship of tree communities with soil factors in upper hill dipterocarp forest of Perak State, Peninsular Malaysia. M.Sc. Thesis. Universiti Kebangsaan Malaysia, Bangi. (unpublished).

[36] Rohani S (2007), Struktur komuniti, variasi flora dan biojisim pokok di Taman Rimba Kenong, Kuala Lipis, Pahang. MSc. Thesis. Universiti Kebangsaan Malaysia, Bangi. (unpublished)

[37] Chua LSL, Suhaida M, Hamidah M \& Saw LG (2010), Malaysia Plant Redlist: Peninsular Malaysian Dipterocarpaceae. Research Pamplet 129. Forest Research Institute of Malaysia (FRIM), Kuala Lumpur p. 210.

[38] Vitousek, P.M., Loope, L.L., Adsersen, H. \& D’Antonio, C.M.(1996). Island ecosystems: do they represent "natural experiments" in biological diversity and ecosystem function?
In:Functional Roles of Biodiversity. A Global Perspective (eds Mooney,H.A., Cushman, J.H., Medina, E., Sala, O.E. \& Schulze, E.-D.).

[39] John Wiley \& Sons Ltd, Chichester, UK, pp. 245-25Vitousek, P.M. Loope, L.L., Adsersen, H. \& D'Antonio, C.M.(1996). Island ecosystems: do they represent " natural experi-ments" in biological diversity and ecosystem function?. In:Functional Roles of Biodiversity. A Global Perspective (eds Mooney,

[40] H.A., Cushman, J.H., Medina, E., Sala, O.E. \& Schulze, E.D.).John Wiley \& Sons Ltd, Chichester, UK, pp. 245-25Vitousek, P.M., Loope, L.L., Adsersen, H. \& D'Antonio, C.M.(1996). Island ecosystems: do they represent "natural experi-ments" in biological diversity and ecosystem function?. In:Functional Roles of Biodiversity. A Global Perspective (eds Mooney,H.A., Cushman, J.H., Medina, E., Sala, O.E. \& Schulze, E.-D.).

[41] John Wiley \& Sons Ltd, Chichester, UK, pp. 245-25Vitousek, P.M. Loope, L.L., Adsersen, H. \& D’Antonio, C.M.(1996). Island ecosystems: do they represent "natural experi-ments" in biological diversity and ecosystem function?. In:Functional Roles of Biodiversity. A Global Perspective (eds Mooney,H.A., Cushman, J.H., Medina, E., Sala, O.E. \& Schulze, E.-D.).John Wiley \& Sons Ltd, Chichester, UK, pp. 245-25 